Arts

\title{
PLANT SYMBOLISM IN PAINTING
}

\author{
Dr (Smt.) Kumud Dubey *1 \\ ${ }^{* 1}$ Associate Professor, (Botany) MLC Govt. P. G. Girls College, Khandwa, India
}

\begin{abstract}
The great flower artists have been those who have found beauty in truth, who have understood plants scientifically and who have yet seen and described them with eye and hand of the artist. Plants, flowers and other foliage symbolize emotions, ideas and actions. Each plant has its own meaning. Painting art and plant illustration is beneficial for modern society because nature inspiring art and art preserving nature.
\end{abstract}

Keywords: Plant Symbolism; Illustration.

Cite This Article: Dr (Smt.) Kumud Dubey. (2019). "PLANT SYMBOLISM IN PAINTING." International Journal of Research - Granthaalayah, 7(11SE), 92-94. https://doi.org/10.29121/granthaalayah.v7.i11.2019.3707.

\section{Introduction}

Plants are not important only to maintain the atmosphere, but also they provide enormous resources. Plant products are essential for human nutrition. Plants create habitats for many organisms; even a single tree may provide food and shelter to many species of insects, worms, birds, reptiles and to small mammals. Plants also serve as material for the art work. The substratram for visual art is often vegetal, spreading pigments on paper. We paint with plant with gum Arabic from Acacia trees in water colors, with oil paints using linseed oil. Plants are the source of charcoal and celluloid films.

In nature plants and flowers inspired artists to create beautiful, graceful paintings for centuries. Artists paint flowers because it is a pleasing endeavor that it is a fun challenge when it comes to color and form. Plants and flowers had a symbolic meaning and so provide a base to artistic ideas to artists.

The present study is made to bring out symbolism of plants in paintings and work of botanical illustrators, it provides an artistic as well as scientific knowledge which is much beneficial and essential to our society. 


\section{Plant Symbolism}

Flowers and plants usually had a symbolic meaning in paintings. Thus a plant could be depicted either as an attribute or giving clues to the identity of subject or providing a moral or philosophical annotation on the subject. Plants, flowers and other foliage symbolize emotions, ideas and actions. Each plant has its own meaning. Early paintings are rich in philosophical and Christian plant symbolism, while $18^{\text {th }}-20^{\text {th }}$ century art movement have added new meanings to vegetal floral symbolism, through the personal perspective of various artists in depicting plant symbols.

Roses traditionally speak of love and beauty. Sunflower expresses happiness, adoration and loyalty. Tulips are symbol of wealth, prosperity, trade and cheer. Orchids are for admiration and love. White irish and white Lily flowers symbolized purity. Ficus used to represent abundance and peace, White Monstera is for honour, respect and longevity. Dianthus (Carnation) represents love and feminity. Gustar Klimt of Vienna painted birch forest which symbolized the season of spring and the rapid growth of young. Bamboo is a symbol for longevity as well as strength and grace. Lotus is a common symbol in Asian art,the lotus symbolizes birth and rebirth through the fact that petals open when the sun comes out and close when the sun sets. Also a symbol of fertility, creation and purity. The long stem symbolizes our connection to our origins, while the flowers represent the enlightenment to which we aspire. Trees and shrubs have been granted multiple meanings. Almond symbolizes prosperity, wisdom, money and a promise. Apple for love, healing and preference, cherry is for kindness, beauty, love, divinisation, Oak is one of the sacred trees of the god Donar, granting protection and symbolizing beauty and fertility. The symbol of trees and flowers has been found to represent physical and spiritual nourishment transformation, liberation, union and fertility.

\section{Botanical Illustrator}

A botanical illustrator is a person who paints, skctches and illustrate botanical subjects. The image in the paintings show the habit and habitat of the plant, details of leaves, flowers, bud, seed and root system. The illustrator is an skilled artist with scientific knowledge about vegetation.

Illustrations are the way of visually recording of plants life. It requires great artistic skills, attention to fine detail and technical horticultural knowledge.

Mariya Sibylla Merian, Redoute, Bayer brothers, Anne pratt, Alexender Marshal, John Dunstall, Elizabeth Blackwell, Sidney Parkinson, W. J. Hooker, W. H. Fitch, N Robert, C. Aubriet, F. Turpin, Jacob Morrel, A Mayer, D. Kandel and many more were famous plant illustrators from England, France, German, Itly and Australia.

In India Mugal painter ustad Mansur in seventeenth century was considered as pioneer illustrator. The art of drawing flowers was unique in his generation. In colonial India Bhawani Das, Rungiah and Govindoo employed and commissioned to make several thousand paintings of plants and flowers by Robert wight in mid nineteenth century. Dara sikoha, Nirupa Rao and many young artists worked and working for art of illustration. 


\section{Concluding Remark}

Plants and blossoms have fascinated painters across time. Early Painters have choosen certain flowers to convey very specific message to their subjects. Unfortunately today, a large part of the symbolism associated with them is lost. Art can open our eyes to the intricacy and beauty of the natural world. Painting as art act as a medium to address pressing environmental issues such as conservation and threatened habitats, sustainability, biodiversity etc., since art can educate the viewers. Plants and flowers usually had a symbolic meaning and bring loads of joy with their natural beauty and awe- inspiring energy, also provide scientific knowledge.

\section{References}

[1] Danial E., (2019), Plant symbolism guide, Pro flowers, https/www.proflowers.com.

[2] Paula C. etal (2015) The Symbolism of garden and orchard plant and their representation in painting. Gardina Botanica L pp 189-200.

[3] Sharma O.P. (2015), Plants and human welfare, Pragati Prakashan Meerut, India

[4] Wilfrid Blunt (2000), The Art of Botanical illustration- an illustrated history, Dover Publication, Inc. New-York. 